Galina V. Verkhova ${ }^{1}$, Sergey V. Akimov', Maxim M. Kotelnikov ${ }^{3} \quad$ DOI: 10.25045/jpit.v10.i2.05 Department of Automation of Communication Enterprises, The Bonch-Bruevich Saint-Petersburg State University of Telecommunications, St. Petersburg, Russia

${ }^{1}$ galina500@inbox.ru, ${ }^{2}$ akimov-sv@ yandex.ru, ${ }^{3}$ max.kat.ru@ mail.ru

\title{
MARKERLESS AUGMENTED REALITY TECHNOLOGY IN MODERN EDUCATION
}

\author{
Received: 21.12.2018 Revised: 27.02.2019 Accepted: 10.03.2019
}

This paper considers the possible directions of using the technology of augmented reality in the modern educational process. It is demonstrated that in the educational process, in most cases, the technology of a non-Marked Augmented Reality has significant advantages over the technology of augmented reality, assuming the use of AR-codes. An example of the use of augmented reality in the training of specialists in the field of automation and management is given.

Keywords: augmented reality, interactive educational technologies, a non-Marked Augmented Reality, augmented reality in the training of specialists in the field of automation and control.

\section{Introduction}

A successful study of the discipline requires the organization of the educational process, which takes into account the individual characteristics of students, and ensures the involvement of the student in the learning process. This requirement assumes wide use of interactive training forms of in modern educational process and dismissal of outdated forms of document circulation, including providing reports on paper.

Augmented reality technology is a learning technology that makes the learning process interactive, increasing the students' degree of visibility and involvement [1-7]. The application of the technology of augmented reality converts the process of using visual aids and mock-ups to a qualitatively new level. This technology will become an integral part of the educational process in the near future, along with the competently created content of modern multimedia teaching and methodological complexes used in modern e-learning systems, educational laboratory equipment and traditional teaching and methodological materials.

A feature of augmented reality technology is the possibility of its effective application with traditional teaching aids (textbooks, posters, laboratory stands) that were created without the consideration of using this technology. Although maximum efficiency of the application of the augmented reality technology can be achieved in educational materials developed in view of its use, existing materials can also be easily adapted to the application of this technology.

\section{Requirements for the technology of augmented reality used in the educational process}

The peculiarity of the use of augmented reality technology in the educational process is the fact that in most cases it is highly undesirable to use augmented reality based on markers (AR-codes). This is due to the specifics of the subject area:

- augmented reality markers take up a lot of space, and cannot always be placed on an educational facility, such as laboratory stands;

- the use of augmented reality markers in teaching aids and other teaching materials and laboratory facilities reduces the quality of the use of these training materials in the case where augmented reality technology is not involved. Consequently, the universality of these training materials is reduced. In addition, the very essence of augmented reality is the "complement" of objects that can be used without the use of this technology.

Markerless augmented reality technologies are devoid of these disadvantages. In addition, such technologies do not require any special adaptation of teaching materials and educational laboratory stands. The system "complements" the physical object with "virtuality", determining its location by using a special pattern recognition algorithm. 
In case of using markerless technologies, the adaptation of traditional teaching materials can be reduced to placing special small symbols informing the student that an augmented reality can be used here. Thus, the use of non-marking technology makes teaching materials equally convenient both in the case of traditional use and in the case of the technology of augmented reality.

Augmented reality markers in the educational process should be used only to set links to information resources in textbooks, slides and information boards when the direct use of hyperlinks for the user is impossible. But even here, in most cases, you should consider the use of markerless augmented reality technologies used in conjunction with symbols that inform the student about the availability of this technology.

Thus, the main requirements for the augmented reality technology used in the learning process are:

- equally convenient use of educational materials in the mode of using the augmented reality technology, and without it;

- avoiding information debris, in the form of markers of augmented reality, placed on the pages of the training manual, slides, posters, and stands;

- minimal adaptation of traditional teaching and methodological materials and existing teaching and laboratory stands to the possibility of effective use of the technology of augmented reality.

\section{Technology of Augmented Reality in the Modern Educational Process}

Traditionally, for the better understanding and assimilation of the material, illustrative material is used, such as tables, diagrams, photographs, slides, printed editions of educational literature, mock-ups, and other visual aids. In connection with the emergence of new technologies, they are being replaced by digital images, presentations, 3D objects, and also the technologies of virtual and augmented realities that are gaining popularity. It is the modern interactive tools and technologies that bring into the learning process the bright three-dimensional images, the game element, activate the interaction of participants in the educational process, develop spatial thinking and skills in project activities.

The technology of augmented reality is necessary to supplement printed material and other physical objects by imposing virtual images. The technology of augmented reality is actively used in advertising, commerce, medicine, games, where it has demonstrated its effectiveness. Competent application of the technology of augmented reality in the learning process will certainly make it more effective and attractive for students. Table 1 presents the possible uses of Augmented Reality technology in education.

The conceptual model [8-11] of using the augmented reality technology in the framework of an interactive educational and methodical complex $(A R-E L)$ is presented in figure 1 . Three key objects are involved in this model: the interactive educational and methodical complex (IEC) of the e-learning system, the supplemented reality module (AR-T) and the supplemented (augmented) object:

$$
A R-E L=\langle I E C, A R-T, O\rangle
$$

A laboratory bench, an image on a computer monitor, a slide or a drawing in a training manual can act as a complementary object. As a module of augmented reality, any mobile device (smartphone, tablet) or glasses of augmented reality can act. The e-learning system used should allow the integration of the resource management module of augmented reality [12-15]. 
The possible uses of Augmented Reality technology in education

\begin{tabular}{|l|l|}
\hline \multicolumn{1}{|c|}{ Directions of use } & \multicolumn{1}{|c|}{ Examples } \\
\hline $\begin{array}{l}\text { Laboratory and practical } \\
\text { work }\end{array}$ & $\begin{array}{l}\text { Guidelines for the implementation of laboratory work, } \\
\text { implemented as a supplemented reality application. This manual } \\
\text { is to support the AR-directory mode. The application of AR- } \\
\text { guidelines for the performance of laboratory works provides the } \\
\text { maximum degree of interactivity of Augmented Reality } \\
\text { technology. }\end{array}$ \\
\hline Modern Textbooks & $\begin{array}{l}\text { Textbooks built on the basis of non-Marker technology } \\
\text { augmented reality. Combines the merits of the advantages of } \\
\text { traditional and interactive technologies, providing the student } \\
\text { with the opportunity to study the material in the most convenient } \\
\text { way for him. The triad is the most effective electronic resource - } \\
\text { a paper publication - augmented reality }\end{array}$ \\
\hline $\begin{array}{l}\text { Use of Augmented Reality } \\
\text { Markers as references to } \\
\text { information sources }\end{array}$ & $\begin{array}{l}\text { Textbooks, methodical materials, diaries, student notebooks, } \\
\text { slides. it is advisable to use markers of augmented reality only as } \\
\text { references to resources, in all other cases, the non-marking } \\
\text { technology of augmented reality is more preferable }\end{array}$ \\
\hline Project Activities & $\begin{array}{l}\text { Creation of blocks, links for demonstration and support of design } \\
\text { solutions }\end{array}$ \\
\hline Informing students & $\begin{array}{l}\text { Substitution of paper ads, comments, announcements using AR } \\
\text { tags, and also by means of a non-marking technology of } \\
\text { augmented reality }\end{array}$ \\
\hline $\begin{array}{l}\text { Demonstration of complex } \\
\text { processes }\end{array}$ & $\begin{array}{l}\text { Detailed reproduction of complex processes, some of which can } \\
\text { not be recreated without the use of specialized technological } \\
\text { equipment. Demonstration of processes can be superimposed on } \\
\text { images placed on visual aids and other educational materials, } \\
\text { including slides }\end{array}$ \\
\hline
\end{tabular}

An example of using the technology of augmented reality in the training of specialists in the field of automation and control in technical systems

Prof. M.A. Bonch-Bruevich of "Automation of communication enterprises" department of St. Petersburg State University of Telecommunications has developed the AR-Tutor software, which ensures the use of markerless and marker technologies of augmented reality in the learning process. Tested operation of this software has shown the promise of using a non-marking technology of augmented reality while training specialists in the field of automation of technological processes and production and management in technical systems.

Figure 2 demonstrates an example of the use of a non-marking technology of augmented reality in conjunction with a traditional printed publication when students study the work of a training laboratory stand. 


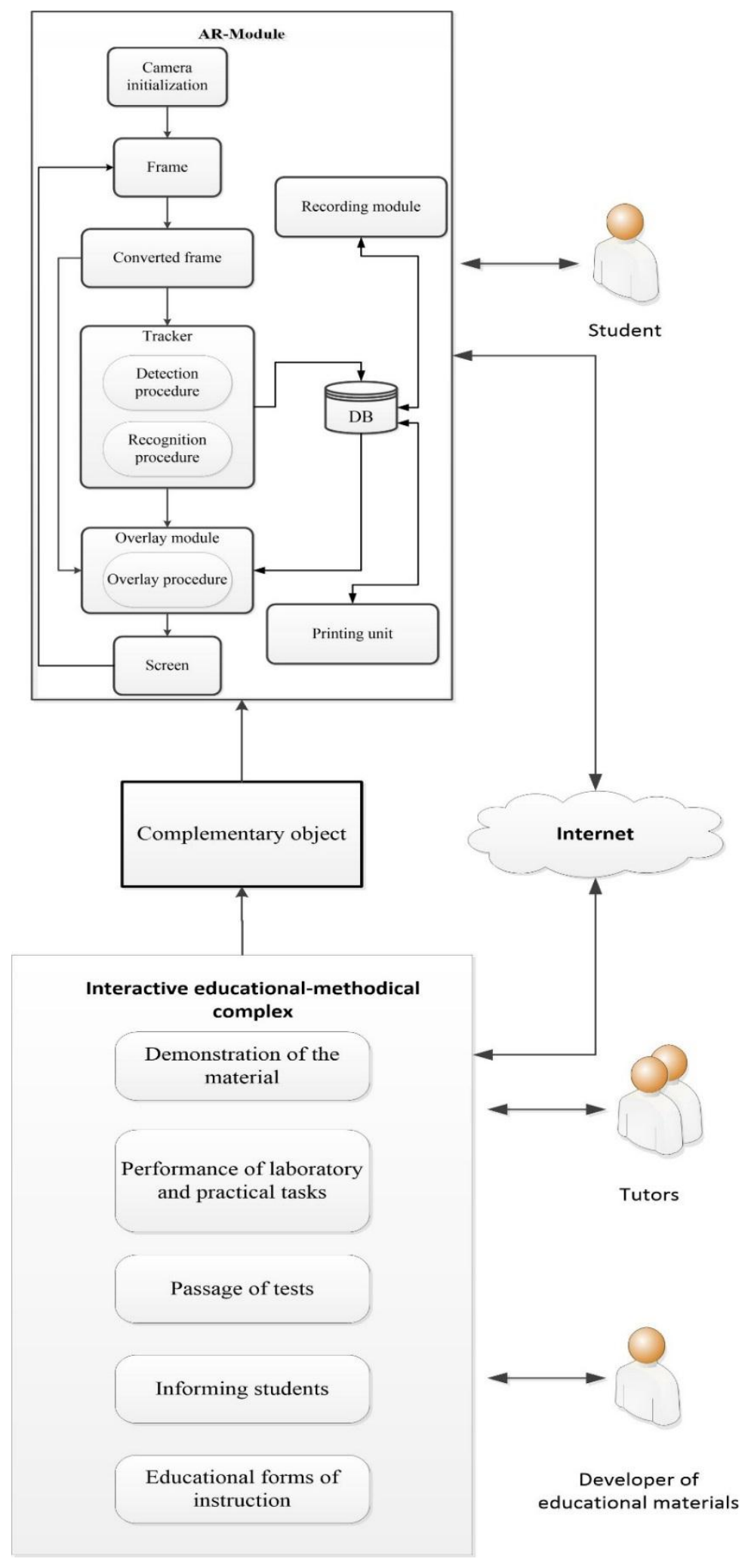

Figure 1. A conceptual model of the learning process using augmented reality technology 


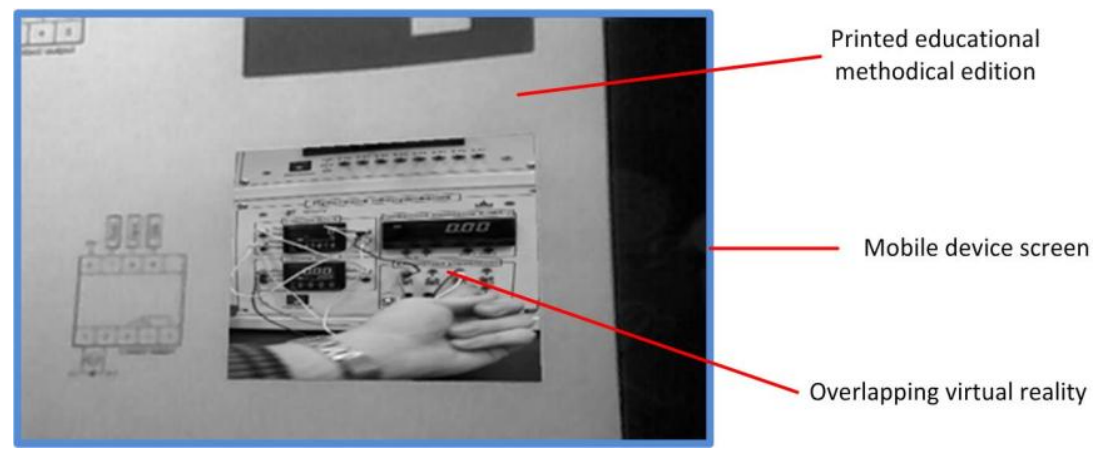

Figure 2. Application of the non-marking technology of augmented reality while studying the functioning of the automation device using a traditional printed training manual

The use of the non-marking technology of augmented reality does not require any substantial reworking of existing teaching aids. As can be seen from figure 2, the virtual addition is directly superimposed on the image in the teaching aid, which is recognized by special software. For comparison, figure 3 shows the use of Augmented Reality technology, based on the use of ARcodes. As you can see, in this case, AR-codes occupy a significant area on the training manual page, completely replacing the image. This example demonstrates the inexpediency of using augmented reality technology based on AR-codes for similar purposes.

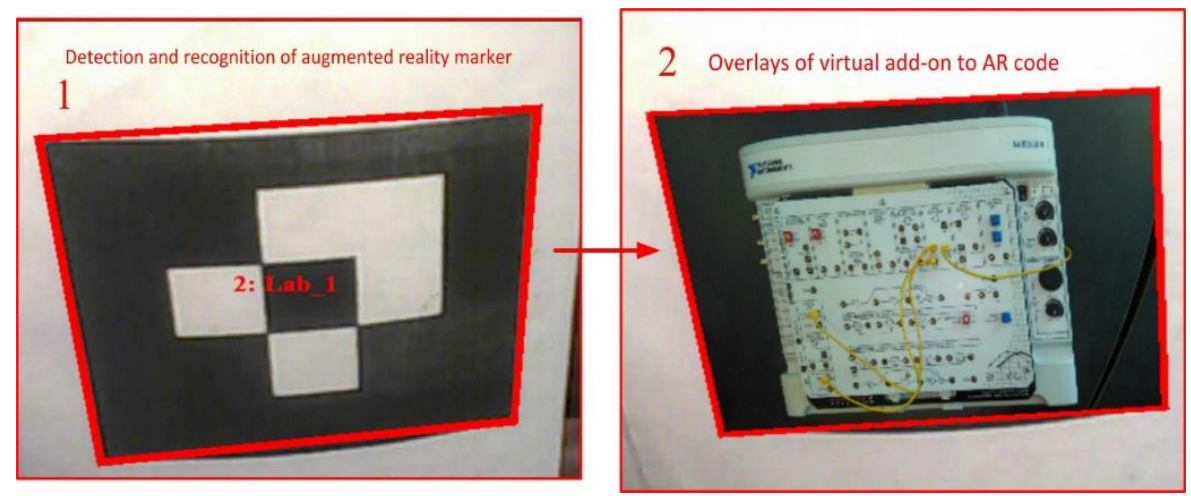

Figure 3. An example of using the technology of augmented, reality-using AR-codes, together with a traditional printed educational publication

Figure 4 demonstrates the use of Augmented Reality technology in preparation of students for laboratory work. In this case, the supplemented reality application is used as an online reference. Virtual addition provides the student with the necessary information, including videos that demonstrate the work with various elements of the training laboratory stand.

Figure 5 shows an example of the student's withdrawal from methodological recommendations, taking into account his individual task.

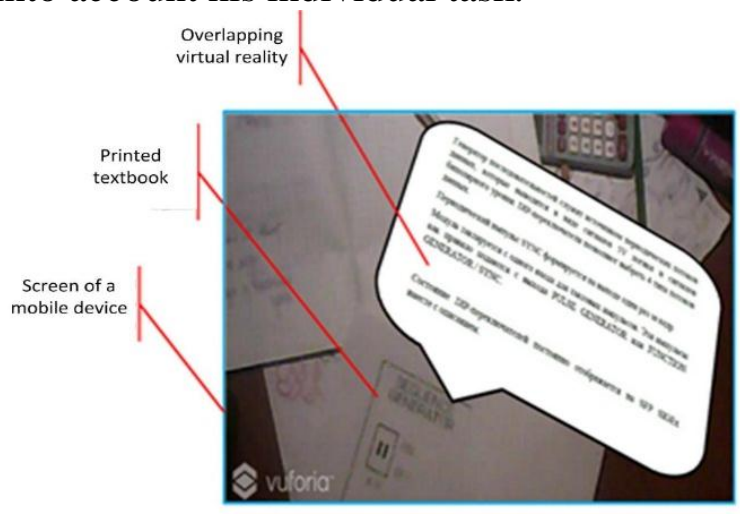

Figure 4. The example of using Augmented Reality technology in preparation for laboratory work. 


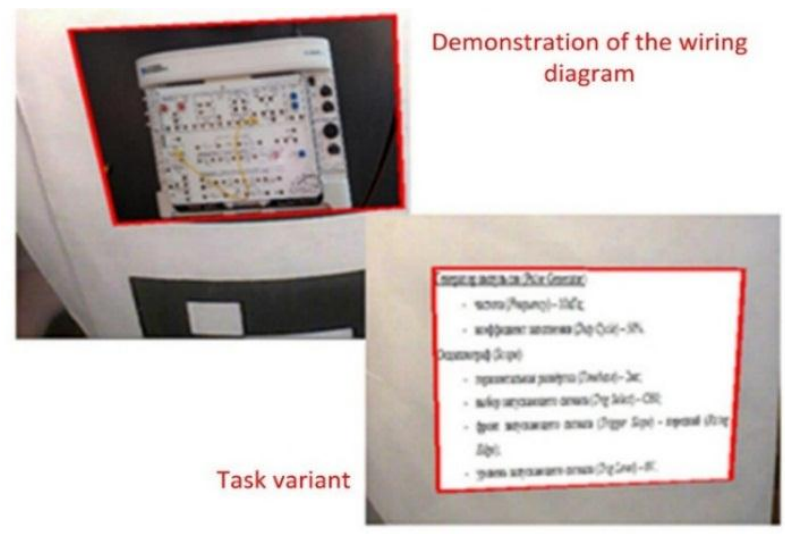

Figure 5. An example of the application of the technology of augmented reality in the process of performing laboratory work

\section{Conclusion}

The use of augmented reality technology in the educational process is apparent from the presented materials. Augmented reality technology can be used as an integral part of the interactive educational and methodical complex of the discipline, as well as with traditional educational materials. Augmented reality technology makes the educational process more interactive, increases the involvement degree of the student in the educational process, allows the student to gain experience with this technology in the field of his future professional activities.

Specifics of the subject area should be taken into account and use the technologies that are adequate to solve specific educational problems. The article shows that in most cases in the educational process it is advisable to use the markerless technology of augmented reality, which provides equally convenient use of educational materials both in the mode of using augmented reality technology and without it. Augmented reality technology based on AR-codes should be used only in cases where it is necessary to provide an information resource with a link, and the direct use of hyperlinks is impossible for the user.

\section{References}

1. Kollatsch C., Schumann M., Klimant P., Lorenz M. Industrial Augmented Reality: Transferring a Numerical Control Connected Augmented Realty System from Marketing to Maintenance / 2017 IEEE International Symposium on Mixed and Augmented Reality (ISMAR-Adjunct), 2017, pp.39-41.

2. Albert A. The Augmented Library: An Approach for Improving Users Awareness in a Campus Library / 2017 IEEE International Symposium on Mixed and Augmented Reality (ISMARAdjunct), 2017, pp.15-19.

3. Yaman O., Karakose M. Development of image processing based methods using augmented reality in higher education / 15th International Conference on Information Technology Based Higher Education and Training (ITHET), 2016, pp.1-5.

4. Verkhova G.V., Akimov S.V., Gusev A.N. Information environment for the training of highly qualified personnel in the system of continuous education / Proceedings of 2017 IEEE 6th Forum Strategic Partnership of Universities and Enterprises of Hi-Tech Branches (Science. Education. Innovations), SPUE 2017, pp.77-80. DOI: 10.1109/IVForum.2017.82 46056.

5. Morey S., Tinnell J. Augmented Reality: Innovative Perspectives across Art, Industry, and Academia. Parlor Press, 2016, 368 p.

6. Verkhova G.V., Akimov S.V. Electronic educational complex for training specialists in the field of technical systems management / Proceedings of 2017 IEEE 2nd International Conference on Control in Technical Systems, CTS 2017, pp.26-29. DOI: 10.1109/CTSYS.2017.8109479.

7. Benderson B.B. Audio Augmented Reality: A Prototype Automated Tour Guide. Archived 1 July 2002 at the Wayback Machine Bell Communications Research / ACM Conference 
Human Factors Computer in Computing Systems, pp.210-211.

8. Verkhova G.V., Akimov S.V. Multi-aspect modeling system objects in CALS / Proceedings of 2017 20th IEEE International Conference on Soft Computing and Measurements (SCM), Russia, St. Petersburg, 2017, pp. 449-451, DOI: 10.1109/SCM.2017.7970614.

9. Akimov S.V., Verkhova G.V., Metkin N.P. Teoreticheskie osnovy CALS. SPb, izdatel'stvo SPbGUT im. prof. M.A. Bonch-Bruevicha, 2018, 263 p.

10. Papagiannis H. Augmented Human: How Technology Is Shaping the New Reality. O'Reilly Media, 2017, $156 \mathrm{p}$.

11. Fournier A. A., Gunawan S. et al.. Common Illumination between Real and Computer Generated Scenes // Proceedings of Graphics Interface '93: Front Matter, 1993, pp.254-262.

12. Leão M., Lima J.P., Teichrieb V., Albuquerqu E.S., Kelner J. Altered reality: Augmenting and diminishing reality in real time / 2011 IEEE Virtual Reality Conference, 2012, pp.219-220.

13. Kollatsch C., Schumann M., Klimant P., Lorenz M. Industrial Augmented Reality: Transferring a Numerical Control Connected Augmented Realty System from Marketing to Maintenance / IEEE International Symposium on Mixed and Augmented Reality (ISMARAdjunct), 2017, pp.39-41.

14. Milgram P., Kishino F. A Taxonomy of Mixed Reality Visual Displays, IEICE Transactions on Information and Systems, 1994, pp.1321-1329.

15. Debbie P., Marusich L. Simulated network effects on tactical operations on decision making / 2015 IEEE International Multi-Disciplinary Conference on Cognitive Methods in Situation Awareness and Decision, pp.145-150.

\section{UOT 004.946}

\section{Verxova Qalina V. ${ }^{1}$, Akimov Sergey V. ${ }^{2}$, Kotelnikov Maksim M. ${ }^{3}$}

M.A. Bonç-Brueviç adına Sankt-Peterburq Dövlət Telekommunikasiya Universiteti, SanktPeterburq, Rusiya

${ }^{1}$ galina500@inbox.ru, ${ }^{2}$ akimov-sv@yandex.ru, ${ }^{3}$ max.kat.ru@ mail.ru

\section{Müasir təhsildə markersiz əlavə reallıq texnologiyası}

Müasir maarifləndirmə prosesində əlavə reallıq texnologiyasından istifadənin mümkün istiqamətlərinə baxılmışdır. Maarifləndirmə prosesində bir çox hallarda markersiz əlavə reallıq texnologiyasının AR-kodlardan istifadəni ehtimal edən əlavə reallıq texnologiyasına nisbətən mühüm üstünlüklərə malik olduğu göstərilmişdir. Avtomatlaşdırma və idarəetmə sahəsi üzrə mütəxəssislərin hazırlığı zamanı əlavə reallıqdan istifadəyə dair nümunə göstərilmişdir.

Açar sözlor: alavo reallıq, interaktiv maariflondirici texnologiyalar, markersiz alavo realliq, avtomatlaşdırma va idarəetmə sahəsində mütəxəssislarin hazırliğında alavə reallıq.

\section{УДК 004.946}

\section{Верхова Галина В. ${ }^{1}$, Акимов Сергей В. ${ }^{2}$, Котельников Максим М. ${ }^{3}$}

Санкт-Петербургский государственный университет телекоммуникаций им. проф. М.А. Бонч-Бруевича

19alina500@inbox.ru, ${ }^{2}$ akimov-sv@ yandex.ru, ${ }^{3}$ max.kat.ru@ mail.ru

\section{Безмаркерная технология дополненной реальности в современном образовании}

Рассмотрены возможные направления использования технологии дополненной реальности в современном образовательном процессе. Показано, что в образовательном процессе в большинстве случаев технология безмаркерной дополненной реальности имеет существенные преимущества перед технологией дополненной реальности, предполагающей использование AR-кодов. Приведен пример использования дополненной реальности при подготовке специалистов в области автоматизации и управления.

Ключевые слова: дополненная реальность, интерактивные образовательные технологии, безмаркерная дополненная реальность, дополненная реальность в подготовке специалистов в области автоматизации и управления. 